\section{Immune response in infants undergoing application of cast: com- parison of halothane and balanced anesthesia}

\author{
Armi Mattila-Vuori $\mathrm{MD},{ }^{\star} \dagger$ \\ Matti Salo MD PhD, ${ }^{*} \dagger$ \\ Eila Iisalo $\mathrm{MD} \mathrm{PhD}^{*}$
}

Purpose: To study the immunological effects of two types of anesthesia on the immune response in infants during a minimally stressful surgical procedure.

Methods: The effects of inhalational halothane (halothane $+\mathrm{N}_{2} \mathrm{O}+\mathrm{O}_{2}$, spontaneous breathing, $\mathrm{n}=12$ ) and conventional balanced anesthesia (thiopental $+\mathrm{N}_{2} \mathrm{O}+\mathrm{O}_{3}+$ fentanyl + vecuronium, mechanical ventilation, $\mathrm{n}=12$ ) on immune function were measured in a crossover study in 12 infants undergoing application of casts to the lower extremity or hip joint. Leukocyte and differential counts, lymphocyte subpopulations, spontaneous lymphocyte proliferative responses as well as responses to phytohemagglutinin (PHA), concavalin $\mathrm{A}(\mathrm{ConA})$ and pokeweed mitogen (PWM), and serum cortisol concentration were measured before, immediately after and four hours after the end of anesthesia.

Results: Halothane anesthesia was associated with a higher percentage of $T$ helper cells than conventional balanced anesthesia $[47.1 \pm 1.8(\mathrm{SEM}) \%, 48.1 \pm 2.3 \%$ and $50.7 \pm 1.9 \%$ before, immediately and four hours after anesthesia vs $45.7 \pm 1.7 \%, 44.0 \pm 2.3 \%$ and $45.1 \pm 1.9 \%$, respectively, by groups, $P<0.05]$. Leukocyte count and the percentages of activated $T$ cells, natural killer cells and B cells showed similar alterations in both groups, and no alterations were observed in the percentages of T lymphocytes or T cytotoxic cells. Lymphocyte transformation response to PWM was decreased four hours after anesthesia in the halothane but not in the balanced anesthesia group.

Conclusion: Anesthesia of short duration during minimal surgical stress alters lymphocyte subpopulations and lymphoproliferative responses in infants and, furthermore, halothane anesthesia and balanced anesthesia have different effects.

Objectif : Étudier les effets immunologiques de deux types d'anesthésie sur la réponse immunitaire pendant une intervention chirurgicale, provoquant peu de stress, chez des enfants.

Méthode : Les effets, sur la fonction immunitaire, de l'halothane, administré par inhalation, (halothane $+\mathrm{N}_{2} \mathrm{O}+$ $\mathrm{O}_{2}$, respiration spontanée, $\mathrm{n}=12$ ) et d'une anesthésie balancée de façon traditionnelle (thiopental $+\mathrm{N}_{2} \mathrm{O}+\mathrm{O}_{2}+$ fentanyl + vécuronium, ventilation mécanique, $n=12$ ) ont été mesurés lors d'une étude croisée auprès de 12 enfants qui devaient recevoir un plâtre au membre inférieur ou à l'articulation coxofémorale. La formule leucocytaire, les sous-populations lymphocytaires, les réponses lymphocytaires prolifératives spontanées aussi bien que les réponses à la phyto-hémagglutinine (PHA), à la concanavaline $\mathrm{A}(\mathrm{Con} A)$ et au mitogène pokeweed (MPW), de même que la concentration de cortisol sérique ont été mesurés avant, immédiatement après et quatre heures après la fin de l'anesthésie.

Résultats : L'anesthésie avec l'halothane a été associée à un plus fort pourcentage de lymphocytes $T$ auxiliaires que l'anesthésie équilbrée de façon courante [47,1 $\pm 1,8 \%$ (erreur type), $48,1 \pm 2,3 \%$ et $50,7 \pm 1,9 \%$ avant, immédiatement et quatre heures après l'anesthésie vs $45,7 \pm 1,7 \%, 44,0 \pm 2,3 \%$ et $45,1 \pm 1,9 \%$, respectivement, par groupe, $P<0,05]$. La formule leucocytaire et les pourcentages de cellules $T$ activées, de lymphocytes tueurs naturels et de lymphocytes B ont montré les mêmes changements chez les enfants des deux groupes, mais aucune modification n'a été observée pour la proportion de lymphocytes $T$ ou de lymphocytes $T$ cytotoxiques. La transformation leucocytaire au MPW avait diminué quatre heures après l'anesthésie chez les enfants qui avaient reçu de l'halothane, mais non chez les autres.

Conclusion : L'anesthésie de courte durée pendant une opération peu stressante modifie les sous-populations lymphocytaires et les réponses lymphoprolifératives chez les enfants. De plus, l'anesthésie à l'halothane et l'anesthésie courante présentent des effets différents.

From the Department of Anaesthesiology, ${ }^{*}$ and Medicity Research Laboratory, $\dagger$ University of Turku, Turku, Finland.

Supported by grants from the Acadeny of Finland, Turku University Foundation and Turku University Central Hospital

Address correspondence to: Dr Armi Mattila-Vuori, Department of Anaesthesiology, Turku University Central Hospital, FIN-20520

Turku, Finland. Fax: +358-2-2613960; E-mail: matti.salo@tyks.fi

Accepted for publication July 14, 1999 
$\mathrm{T}$

HE effect of anesthesia on the immune response is poorly understood, especially in small children and infants. Anesthesia and surgery together affect immune responses, ${ }^{1}$ resulting in suppression of lymphocyte function. ${ }^{2}$ Puri et al. found that neonates recovered their mitogeninduced lymphocyte responsiveness slowly after anesthesia and operation and that the immunosuppressive effect was more marked in neonates than in older children. ${ }^{3}$ This suggests that the functional capacity of neonatal lymphocytes is different from that of older children and possibly reflects the immature status of neonatal immune competence. The role of anesthetic agents in immunodepression is, however, unclear. In vitro, most anesthetics have been found to inhibit mitogen-induced lymphocyte transformation and other lymphocyte/leukocyte responses but usually at higher concentrations and after longer exposure than found in the clinical practice..$^{4-8}$ We wanted to measure the effects of anesthesia on the immune response in infants and to compare the effects of two different anesthesia techniques (inhalational halothane anesthesia and conventional balanced anesthesia) without the interference of surgical trauma, which is a new approach.

\section{Methods}

This study was approved by the Ethics Committee of Turku University Medical Faculty and Turku University Central Hospital. The study was conducted in accordance with the principles for human experimentation defined in the Declaration of Helsinki. Written informed consent was obtained from the parents.

\section{Patients}

Twelve infants with uni- or bilateral clubfoot or hip dislocation were anesthetized for application of a cast on the lower extremity or hip joint, each with inhalational halothane anesthesia or conventional balanced anesthesia in a randomized order, at two to four weeks' interval. All infants were born at term, and their mean weight at the time of the first administration of anesthesia was $7050 \mathrm{~g} \pm 1260$ (SD), range $5300-9000 \mathrm{~g}$. Their mean age during conventional balanced anesthesia was $17 \mathrm{wk} \pm 2 \mathrm{wk}$, range $14-20$ $\mathrm{wk}$, and during inhalational halothane anesthesia 16 $w \mathrm{k} \pm 4 \mathrm{wk}$, range $12-23 \mathrm{wk}$. The mean duration of halothane anesthesia was $25 \pm 7 \mathrm{~min}$, range $15-40$ $\mathrm{min}$, which did not differ from the duration of conventional balanced anesthesia, mean $30 \pm 10 \mathrm{~min}$, range $20-53 \mathrm{~min}$.

The infants received no premedication before they were taken to the operating room, which is our routine in infants. The first blood samples were taken at introduction of the $i v$ cannula, and all children were given $0.02 \mathrm{mg} \cdot \mathrm{kg}^{-1}$ atropine $i \mathrm{p}$ irrespective of the type of anesthesia. Second blood samples were taken via the $i p$-cannula immediately after the end of anesthesia. During and after the procedure, both groups received $4 \mathrm{ml} \cdot \mathrm{kg}^{-1} \cdot \mathrm{hr}^{-1}$ of an isotonic solution containing glucose $5 \%$, until the last blood samples were taken four hours after the end of anesthesia.

In the inhalational halothane anesthesia group, halothane-nitrous oxide-oxygen-anesthesia was induced through a mask with halothane $2 \%$ as the vaporizer setting added to nitrous oxide $70 \%$ in oxygen, and all patients fell asleep in one to two minutes without any airway problems. Anesthesia was maintained with halothane $1-2 \%$ in nitrous oxide $70 \%$ in oxygen. At the end of anesthesia patients inhaled oxygen $100 \%$ until they woke up.

In the conventional balanced anesthesia group, anesthesia was induced using $0.002 \mathrm{mg} \cdot \mathrm{kg}^{-1}$ fentanyl and $5 \mathrm{mg} \cdot \mathrm{kg}^{-1}$ thiopental. Vecuronium $0.1 \mathrm{mg} \cdot \mathrm{kg}^{-1}$ was given to facilitate tracheal intubation. Fentanyl, $0.001 \mathrm{mg} \cdot \mathrm{kg}^{-1}$, was given if the blood pressure or heart rate increased by more than $10 \%$ of steady state values. Muscle relaxation was monitored using a peripheral neurostimulator, and $0.03 \mathrm{mg} \cdot \mathrm{kg}^{-1}$ vecuronium was administered when necessary. The lungs were ventilated mechanically with nitrous oxide $70 \%$ in oxygen, maintaining expiratory end tidal carbon dioxide concentrations at $4-6 \%$. At the end of anesthesia, neuromuscular blockade was antagonised using $0.02 \mathrm{mg} \cdot \mathrm{kg}^{-1}$ atropine and $0.05 \mathrm{mg} \cdot \mathrm{kg}^{-1}$ neostigmine.

Blood samples for leukocyte and differential counts, identification of lymphocyte subpopulations, measurement of lymphocyte proliferative responses and measurement of serum cortisol concentration were taken 1 ) immediately before anesthesia, 2) immediately after the end of anesthesia when the patient was awake and 3) four hours after the end of anesthesia. Leukocyte and differential counts were determined using the $\mathrm{H} 6000$ blood cell analyzer (Technicon Instruments Co., Tarrytown, NY, USA).

\section{Identification of lymphocyte subpopulations}

For identification of lymphocyte subpopulations and monocytes, the Simultest whole blood technique for simultaneous two-colour immunofluorescence staining was used. The following pairs of murine antihuman antibodies conjugated to fluorescein isothiocyanate (FITC) or phycoerythrin (PE) were used: 1) CD3 (T lymphocytes) and CD19 (B lymphocytes), 2) CD4 (T helper cells) and CD8 ( $\mathrm{T}$ cytotoxic cells), 3) CD3 and CD16+CD56 (natural killer cells), 4) CD3 and HLADr (activated $\mathrm{T}$ lymphocytes) and 5) negative control 
(IgG1, FITC/IgG2a, PE) (Becton Dickinson, CA, USA). The light-scatter gate was defined by antiCD45/anti-CD 14/Simultest LeukoGATE (Becton Dickinson) to distinguish lymphocytes from granulocytes, monocytes and unlysed red blood cells.

One hundred microlitres of heparinized whole blood were mixed and incubated for $30 \mathrm{~min}$ at $37^{\circ} \mathrm{C}$ with appropriate dilutions of each pair of monoclonal antibody in separate tubes. Erythrocytes were then removed by lysis through the addition of FACS $®$ Lysin solution (Becton Dickinson) to the tubes. The cells were fixed in a buffered paraformaldehyde $1 \%$ solution prior to flow cytometry analysis (FACScan ${ }^{\mathrm{TM}}$, Becton Dickinson) using the SimulSET ${ }^{\mathrm{TM}}$ software (Becton Dickinson). The results are expressed as percentages of lymphocytes positive for each phenotype.

\section{Measurement of lymphocyte proliferative responses}

Twenty-five microlitres of heparinized whole blood were cultured in triplicate in RPMI 1640 medium (Gibco, Grand Island, NY, USA) with $50 \mu \mathrm{g} \cdot \mathrm{ml}^{-1} \mathrm{gen}$ - tamicin and $125 \mu \mathrm{g} \cdot \mathrm{ml}^{-1}$ phytohemagglutinin $\mathrm{M}$ (PHA, Difco Laboratories, Detroit, Mich., USA), 25 $\mu \mathrm{g} \cdot \mathrm{ml}^{-1}$ concavalin A (Con A, Pharmacia Fine Chemicals, Uppsala, Sweden) or pokeweed mitogen (PWM, Gibco) 2,5 $\mathrm{\mu g} \cdot \mathrm{ml}^{-1}$ as final concentration in wells of flat-bottomed microtitre plates (A/S Nunc, Roskilde, Denmark) in humidified air and $\mathrm{CO}_{2} 5 \%$ at $37^{\circ} \mathrm{C}$ for $96 \mathrm{hr} .^{9}$ Eighteen hours before harvesting, $0.5 \mu \mathrm{Ci}$ tritiated thymidine (The Radiochemical Centre, Amersham, U.K.) was added in volume of 20 $\mu l$ to each well. The cultures were harvested with a multiple cell-culture harvester (Skatron, Liebyen, Norway), and thymidine uptake was measured using an automatic liquid scintillation counter (LKB Wallac, Turku, Finland). The results are expressed as disintegrations per minute (dpm).

\section{Measurement of serum cortisol concentration}

Serum cortisol concentrations were measured using a radioimmunoassay kit $\left({ }^{125} \mathrm{~J}\right)$ from Farmos Diagnostica (Turku, Finland).

TABLE I Leukocyte and their differential counts, and lymphocyte subsets.

\begin{tabular}{|c|c|c|c|c|}
\hline & $\begin{array}{l}\text { Before } \\
\text { anesthesia }\end{array}$ & $\begin{array}{l}\text { Immediately } \\
\text { after anesthesia }\end{array}$ & $\begin{array}{l}\text { Four bours } \\
\text { after anesthesia }\end{array}$ & $P$ \\
\hline \multicolumn{5}{|l|}{ Leukocytes, $10^{9}$ litre ${ }^{-1}$} \\
\hline Halothane & $10.3 \pm 0.6$ & $8.6 \pm 0.8 \ddagger$ & $8.2 \pm 1.0^{*}$ & \\
\hline Balanced anesthesia & $12.8 \pm 1.5$ & $9.0 \pm 1.0 \ddagger$ & $8.3 \pm 0.8^{\star}$ & \\
\hline \multicolumn{5}{|l|}{ Neutrophils, \% } \\
\hline Halothane & $26.8 \pm 1.8$ & $28.4 \pm 1.5^{*}$ & $28.8 \pm 2.9^{\star}$ & \\
\hline Balanced anesthesia & $27.3 \pm 2.6$ & $30.0 \pm 3.3^{*}$ & $39.2 \pm 3.5^{\star}$ & \\
\hline \multicolumn{5}{|l|}{ Lymphocytes, \% } \\
\hline Halothane & $59.8 \pm 3.1$ & $58.6 \pm 2.8$ & $60.4 \pm 3.7$ & \\
\hline Balanced anesthesia & $59.4 \pm 3.2$ & $57.5 \pm 4.0$ & $50.3 \pm 5.2 \dagger$ & \\
\hline \multicolumn{5}{|l|}{ T cells (CD3), \% } \\
\hline Halothane & $63.3 \pm 1.9$ & $63.9 \pm 2.8$ & $67.6 \pm 2.2$ & \\
\hline Balanced anesthesia & $62.2 \pm 1.9$ & $59.9 \pm 2.5$ & $62.9 \pm 2.3$ & \\
\hline \multicolumn{5}{|l|}{$T$ belper cells (CD4), \% } \\
\hline Halothane & $47.1 \pm 1.8$ & $48.1 \pm 2.3$ & $50.7 \pm 1.9$ & \\
\hline Balanced anesthesia & $45.7 \pm 1.7$ & $44.0 \pm 2.3$ & $45.1 \pm 1.9$ & $<0.05$ \\
\hline \multicolumn{5}{|l|}{ T cytotoxic cells (CD8), \% } \\
\hline Halothane & $15.8 \pm 1.4$ & $14.6 \pm 1.1$ & $15.8 \pm 1.5$ & \\
\hline Balanced anesthesia & $15.7 \pm 1.2$ & $14.7 \pm 1.0$ & $15.5 \pm 0.9$ & \\
\hline \multicolumn{5}{|c|}{ Natural killer cells $(C D 3+C D 16+C D 56), \%$} \\
\hline Halothane & $13.3 \pm 1.2$ & $7.2 \pm 0.7 \ddagger$ & $6.9 \pm 1.1 \ddagger$ & \\
\hline Balanced ancsthesia & $12.0 \pm 1.3$ & $8.4 \pm 1.2 \ddagger$ & $8.2 \pm 1.1 \ddagger$ & \\
\hline \multicolumn{5}{|c|}{ Activated T cells $(C D 3+H L A-D r), \%$} \\
\hline Halothane & $25.3 \pm 2.5$ & $30.6 \pm 2.6 \ddagger$ & $27.1 \pm 3.5^{*}$ & \\
\hline Balanced anesthesia & $26.5 \pm 2.2$ & $32.7 \pm 2.7 \ddagger$ & $31.2 \pm 2.2^{*}$ & \\
\hline \multicolumn{5}{|l|}{$B$ cells $(C D 19), \%$} \\
\hline Halothane & $22.3 \pm 2.3$ & $26.8 \pm 2.5 \ddagger$ & $25.0 \pm 2.8$ & \\
\hline Balanced anesthesia & $23.3 \pm 2.2$ & $29.4 \pm 2.3 \ddagger$ & $27.7 \pm 2.3$ & \\
\hline
\end{tabular}

Mean \pm SEM

No statistically significant differences between groups before anesthesia

Asterixes: ${ }^{*}=P<0.05, \dagger=P<0.01, \ddagger=P<0.001$ in relation to preanesthetic value

$P$ - values refer to intergroup differences 
TABLE II Lymphocyte transformation responses

\begin{tabular}{|c|c|c|c|c|c|c|}
\hline \multirow{2}{*}{ Spontaneous, dpm } & \multicolumn{2}{|c|}{$\begin{array}{l}\text { Before } \\
\text { anesthesia }\end{array}$} & \multicolumn{2}{|c|}{$\begin{array}{l}\text { Immediately } \\
\text { after anesthesia }\end{array}$} & \multicolumn{2}{|c|}{$\begin{array}{l}\text { Four bours } \\
\text { after anesthesia }\end{array}$} \\
\hline & & & & & & \\
\hline Halothane & 482 & $(406-637)$ & 398 & $(271-523)$ & 410 & $(204-480)$ \\
\hline Balanced anesthesia & 613 & $(525-885)$ & 607 & $(420-721)$ & 758 & $(488-1002)$ \\
\hline \multicolumn{7}{|l|}{$P H A, d p m$} \\
\hline Halothane & 172552 & $(51606-422181)$ & 76964 & $(29475-217973)$ & 233203 & $(37601-470773)$ \\
\hline Balanced anesthesia & 191522 & $(160291-225199)$ & 203072 & $(139856-398767)$ & 265403 & $(159707-421734)$ \\
\hline \multicolumn{7}{|l|}{$\operatorname{Con} A, d p m$} \\
\hline Halothane & 442210 & $(200948-469189)$ & 239871 & $(128858-340713)$ & 206320 & $(126954-401369)$ \\
\hline Balanced anesthesia & 367951 & $(284155-490274)$ & 293505 & $(206453-414925)$ & 340898 & $(270531-509770)$ \\
\hline \multicolumn{7}{|l|}{$P W M, d p m$} \\
\hline Halothane & 20773 & $(3316-43491)$ & 9426 & $(4637-20696)$ & 7935 & $(4505-17178)^{\star}$ \\
\hline Balanced anesthesia & 25775 & $(6763-44568)$ & 17167 & $(3506-30135)$ & 18467 & $(4924-70365)$ \\
\hline
\end{tabular}

PHA = phytohemagglutinin, Con $\mathrm{A}=$ concavalin $\mathrm{A}, \mathrm{PWM}=$ pokeweed mitogen Median (25th and 75th percentiles) $\mathrm{dpm}=$ disintegrations per $\min$ Asterixes: ${ }^{*}=P<0.05$ in relation to preanesthetic value No statistically significant differences between the groups before anesthesia

TABLE III Serum cortisol concentrations

\begin{tabular}{llll}
\hline & $\begin{array}{l}\text { Before } \\
\text { anesthesia }\end{array}$ & $\begin{array}{l}\text { Immediately } \\
\text { after anesthesia }\end{array}$ & $\begin{array}{l}\text { Four hours } \\
\text { after anesthesia }\end{array}$ \\
\hline Cortisol nmol.litre-1 & & & \\
Halothane & $481(298-546)$ & $542(370-662)$ & $340(229-425)$ \\
Balanced anesthesia & $502(381-619)$ & $441(235-665)$ & $361(278-492)$ \\
\hline
\end{tabular}

Median (25th and 75 percentiles)

\section{Statistics}

The SYSTAT system (Evanston, Ill., USA) was used for the statistical analysis of the data on a digital computer. The subprogram used was an univariate and multivariate repeated measures analysis of variance with two within factors (type of anesthesia and time). Student's $t$ test was used as the posthoc test. In the overall analysis, logarithmic transformation was used to normalize the distribution of lymphocyte proliferative response and serum cortisol values. The results are presented as mean values and standard errors of the mean (SEM) or medians and quartiles. Values of $P<$ 0.05 are considered to indicate statistical significance.

\section{Results}

All laboratory test values were similar between the groups before anesthesia. The only difference in the overall statistical analysis was that the percentages of $T$ helper cells (CD4) were greater in the halothane than in the balanced anesthesia group $(P<0.05)$ (Table I).
Other laboratory tests showed alterations but without overall differences between the groups, or no alterations. The leukocyte counts were decreased at the end of anesthesia $(P<0.001)$ and four hours after anesthesia $(P<0.05)$ in both groups without differences between the groups (Table I). The percentages of neutrophils were increased at the end of anesthesia $(P<$ $0.05)$ and four hours after anesthesia $(P<0.05)$. The percentages of lymphocytes were decreased in the balanced anesthesia group four hours after anesthesia $(P<$ 0.01 ), but this decrease was not seen in the inhalational halothane anesthesia group. The percentages of $\mathrm{T}$ lymphocytes (CD3) and T cytotoxic cells (CD8) remained unchanged in both groups during the followup. By contrast, the percentages of activated $T$ cells (HLA-Dr-positive T cells) were increased immediately after anesthesia in both groups $(P<0.001)$, and returned slightly towards the preoperative level at four hours after anesthesia. The percentages of natural killer cells (CD3+CD16+CD56) decreased in both anesthesia groups, remaining low throughout the four-hour period $(P<0.001)$. The percentages of $\mathrm{B}$ lymphocytes (CD19) were increased after anesthesia in both groups without any differences between the groups.

The lymphocyte proliferative response to PWM was decreased four hours after halothane anesthesia $(P<$ 0.05 ), which was the only statistically significant change in lymphocyte proliferative responses (Table II).

The serum cortisol concentration of 481 (298-546) nmol.litre ${ }^{-1}$ in the halothane group and 502 (381-619) nmol-litre ${ }^{-1}$ in the balanced anesthesia group did not 
change during or after anesthesia, and no differences were seen between the groups (Table III).

\section{Discussion}

As a new finding, this study showed that clinical anesthesia can produce alterations in the immune response in infants. The two types of anesthesia, inhalational halothane and conventional balanced anesthesia with thiopental $+\mathrm{O}_{2}+\mathrm{N}_{2} \mathrm{O}+$ fentanyl + vecuronium produced a same-type immune response with a difference only in the percentage of $T$ helper cells between the anesthesia methods. Quantification of effector cell numbers showed similar alterations in the groups for leukocyte count and for the percentages of activated T-cells, natural killer cells and B-cells. However, a shift in blood leukocytes was observed in the balanced anesthesia group as increased percentage of neutrophils and decreased percentage of lymphocytes which was not as such observed in the halothane group. The increase in the percentage of activated $T$ cells and B-cells observed after both types of anesthesia are well-known accompanuates of surgery. The difference between the groups seen in the percentages of $\mathrm{T}$ helper cells four hours after anesthesia was not statistically significant different within the groups. Changes in the balance between T-helper type- 1 - and type- 2 cells were not tested. The percentage of natural killer cells (NK) decreased immediately and four hours after halothane and balanced anesthesia. Remarkable in this study was the decreased PWMinduced lymphocyte proliferative response in the halothane inhalational anesthesia group which was not observed in the balanced anesthesia group.

Most earlier studies have measured the effects of different types of anesthesia during operation, ${ }^{2-3}$ in which the effects of surgical trauma cannot be excluded as a cause of changes in the immune response. In this study we compared the effects during application of a cast which is a non-invasive, minimally stressful procedure and unlikely to produce alterations in the immune response itself. The serum cortisol concentrations were measured as indicators of stress. Similar concentrations and lack of cortisol response during the follow-up period point to a stress-free situation in both groups. This study can thus be considered to measure the effects of anesthesia alone. To minimize interindividual variation each patient was anesthetized in a randomized order with either method of anesthesia.

The decrease in leukocyte count observed in this study has earlier been reported during anesthesia in animals, ${ }^{10}$ whereas anesthesia and surgery typically produce leukocytosis. An increased percentage of Thelper cells has been previously observed during propofol-based total intravenous anesthesia compared with conventional thiopental+fentanyl-based balanced anesthesia in adult patients undergoing minor surgery, ${ }^{11}$ and we found an increased percentage during halothane anesthesia. The next step would be to compare inhalational anesthesia and propofol anesthesia during minimally stressful procedures. Most studies have found T-helper and T-cytotoxic cells to decrease after surgery and their proportions to change in favour of T-cytotoxic cells with increasing trauma severity. ${ }^{1}$ Differences in type-I- and type-2-like responses have also been observed between different anesthetics in vitro. ${ }^{12}$ The decrease of natural killer cell (NK) percentage in our work is in line with previous studies in adults showing an increase in natural killer cell activity after premedication and induction of anesthesia, followed by postoperative decrease., ${ }^{1,12-14}$

Minor or no effects of anesthetics on the immune response have been demonstrated in adults in vivo. Duncan et al. found that halothane anesthesia, in humans, was not associated with alterations in lymphocyte transformation in response to PHA in the absence of surgery, ${ }^{15}$ and similar observations have been made in other studies on patients undergoing minimal surgical trauma. ${ }^{16}$ On the other hand, in vitro studies in adults have shown that anesthetics inhibit mitogen-induced lymphocyte transformation and anesthesia and surgery together are known to depress lymphocyte proliferative responses. ${ }^{1,3,17-18}$ Thiopental has depressive effects on monocyte-mediated cytolysis and PHA-induced lymphocyte proliferative responses in concentrations relevant to anesthetic practice $e^{5-6}$ and halothane has also been found to inhibit interferon release from monocytes and lymphocytes in vitro. ${ }^{19}$ Furthermore, at clinical concentrations it seems to inhibit mitogen-induced lymphocyte transformation. $^{7-8}$ In neonates, responsiveness to mitogens (PHA, ConA, PWM, SPA) was reduced immediately after surgery and only PHA-response had recovered after $24 \mathrm{hr}$ in a study by Puri $e t$ al. ${ }^{20}$

The changes can be partly explained by the immaturity of the infant immune system. Leukocyte, lymphocyte and its subset counts are known to change with age, and the changes are most marked during the first five years of life. Total leukocyte and lymphocyte counts are highest at the age of six months. T-helper and T-cytotoxic lymphocyte counts and the percentages of T-helper cells decrease considerably with age from two months to six years, while the percentages of T-cytotoxic cells increase over the same period. ${ }^{21-22}$ Mollit $e t a l$. found an age- dependency in operativeinduced alteration of lymphocyte function in children. A decrease in lymphocyte, $T$ and $B$ cell counts as well 
as a depression of lymphocyte reactivity and alteration in B cell response to PWM were all inversely related to age from one month to $12 \mathrm{yr}^{23}$

In conclusion, the novel finding of the present study is that anesthesia of short duration without surgical invasive trauma is sufficient to alter infants' lymphocyte subpopulations and lymphoproliferative responses in blood circulation. These findings can be explained by the immaturity of infant immune system. As the changes were observed in shorter period than the halflife of effector cells, they probably are due to redistribution of effector cells. To the inter-group difference in $T$ helper cells we have no explanation. Further investigations are needed to clarify the role of anesthesia in immune depression and the underlying mechanisms in infants. The changes were minor and as such, need not be of any clinical consequence considering that these changes are reversible and no per- or postoperative complications were observed. These findings, however, represent only a part of the alterations in host defences and, therefore, also other aspects of host defences should be studied before final conclusions.

\section{Acknowledgments}

Mrs Marjo Hakkarainen is acknowledged for her skillful technical assistance and Hans Helenius msc, Department of Medical Biostatistics, University of Turku, for help in the statistical analyses. This study was supported by grants from the Academy of Finland, Turku University Foundation and Turku University Central Hospital.

\section{References}

1 Salo $M$. Effects of anaesthesia and surgery on the immune response. Acta Anaesthesiol Scand 1992; 36: 201-20.

2 Rybänen P. Effects of anesthesia and operative surgery on the immune response of patients in different ages. Ann Clin Res 1978; 9(Suppl 19).

3 Puri P, Brazil J, Reen DJ. Immunosuppressive effects of anesthesia and surgery in the newborn: I short- term effects. J Ped Surg 1984; 19: 823-8.

4 Moudgil GC. Effect of premedicants, intravenous anaesthetic agents and local anaesthethics on phagocytosis in vitro. Can Anaesth Soc J 1981; 28: 597-602.

5 Devlin EG, Clarke RSJ, Mirakhur RK, McNeill TA. Effect of four i.v. induction agents on T-lymphocyte proliferations to PHA in vitro. Br J Anaesth 1994; 73: 315-7.

6 Hole $A$. Depression of monocytes and lymphocytes by stress-related humoral factors and anaesthetic- related drugs. Acta Anaesthesiol Scand 1984; 28: 280-6.
7 Cullen BF, Sample WF, Chretien PB. The effect of halothane on phytohemagglutinin-induced transformation of human lymphocytes in vitro. Anesthesiology 1972; 36: 206-12.

8 Bruce $D L$. Halothane inhibition of phytohemagglutinin-induced transformation of lymphocytes. Anesthesiology 1972; 36: 201-5.

9 Eskola J, Soppi E, Viljanen M, Ruuskanen O. A new micromethod for lymphocyte stimulation using whole blood. Immunol Commun 1975; 4: 297-307.

10 Usenik EA, Cronkite EP. Effects of barbiturate anesthetics on leukocytes in normal and splenectomized dogs. Anesth Analg 1965; 44: 167.

11 Pirttikangas C-O, Perttilä J, Salo M, Vainio O, LiukkoSipi $S$. Propofol infusion anaesthesia and immune response in minor surgery. Anaesthesia 1994; 49: 13-6.

12 Salo M, Pirttikangas C-O, Pulkki K. Effects of propofol emulsion and thiopentone on $T$ helper cell type1/type-2 balance in vitro. Anaesthesia 1997: 52; $341-4$.

13 Pirttikangas $C-O$, Salo $M$, Peltola $O$. Propofol infusion anaesthesia and the immune response in elderly patients undergoing ophthalmic surgery. Anaesthesia 1996: 51; 318-23.

14 Hauser GJ, Chan MM, Casey WF, Midgley FM, Holbrook $P R$. Immune dysfunction in children after corrective surgery for congenital heart disease. Crit Care Med 1991; 19: 874-81.

15 Duncan PG, Cullen BF, Calverly R, Smith NT, Eger EI $I I$, Bone $R$. Failure of enflurane and halothane anesthesia to inhibit lymphocyte transformation in volunteers. Anesthesiology 1976; 45: 661-5.

16 Kanto J, Vapaavuori M, Viljanen MK. Mitogeninduced lymphocyte transformation after general anaesthesia. Br J Anaesth 1974; 46: 733-5.

17 Tonnesen E, Brinkløv MM, Christensen NJ, Olesen AS, Madsen $T$. Natural killer cell activity and lymphocyte function during and after coronary artery bypass grafting in relation to the endocrine stress response. Anesthesiology 1987; 67: 526-33.

18 Edwards AE, Gemmell LW, Mankin PP, Smith CJ, Allen $J C$, Hunter $A$. The effects of three differing anaesthetics on the immune response. Anaesthesia 1984; 39: 1071-8.

19 Stevenson GW, Hall S, Miller PJ, et al. The effect of anesthetic agents on human immune system function. I. Design of a system to deliver inhalational anesthetic agents to leukocyte cultures in vitro. J Immunol Methods 1986; 88: 277-83.

20 Puri $P$, Blake $P$, Reen DJ, Guiney EJ. Lymphocyte transformation after surgery in the neonate. J Pediatr Surg $1980 ; 15: 175-7$. 
21 Denny $T, Y_{0}$ gev $R$, Gelman $R$, et al. Lymphocyte subsets in healthy children during the first 5 years of life. JAMA 1992; 4267: 1484-8.

22 Stiebm ER. Immunologic Disorders in Infants \& Children, 4th ed. Philadelphia: WB Saunders Company, 1996: 221

23 Mollitt DL, Marmer DJ, Steele RW. Age-dependent variation of lymphocyte function in the postoperative child. J Pediatr Surg 1986; 21: 633-5. 